\title{
Parallelism and Metaphor in Death Ritual Speech Rambu Soloq at Toraja Culture
}

\author{
Naomi Patiung ${ }^{1}$, Tadjuddin Maknun ${ }^{2}$, Marthen L. Manda ${ }^{3}$, Hamzah Machmoed ${ }^{4}$ \\ 1, 2, 3, ${ }^{4}$ Hasanuddin University, Faculty of Cultural Sciences, St. Perintis Kemerdekaan, Makassar, Indonesia
}

\begin{abstract}
This study aims to explain parallelism and metaphor in Osongchant death ritual speech and Mebala Kollong speechat ritual ceremony Rambu Soloqat Toraja culture.This study was a participative observation conducted in Ao Gading village, Sa'danand Balusu district of North Toraja regency, South Sulawesi, Indonesia. The data werein the form of social situations and events ie. Osong and Mebala Kollong speech obtained through recording, interview, and note taking. The data were analyzed by interpretive-qualitative technique.The results showed that denotative utterances of Osong deathchant ritual speech and Mebala Kollong speech constructed by some kinds of style such as a metaphor, parallelism, symbolic, tautology, and repetition. While, connotatively-symbolic this ritual speech expressed social relations and values of socio-cultural forms of supplication, reverence, worship, praise, hope, majesty, prayers and others.
\end{abstract}

Keywords: Rambu Soloq, parallelism, metaphor, Osong and Mebala Kollong

\section{Introduction}

North Toraja is one of regencies as a tourism center in South Sulawesi particularly and in eastern Indonesia generally. This area is famous not only for its natural beauty but also for the lives of people who embrace the unique cultural heritage of their ancestors, known as Aluk Todolo or Alukta, the ancestral religion. Their religion has been implemented in their daily lives either in thanksgiving ceremony commonly called Rambu Tukaq ceremony or in grief or death ceremony called Rambu Soloq. Rambu Tukaq (smoke rises) or Rampe Matallo (east) is a ceremony held when the sun moves up from the eastern horizon in the morning until noon. Conversely, Rambu Soloq (smoke down) or Matampu Rampeq (west) is a ceremony held when the sun is leaning to the west from noon until late afternoon and evening.

In relation with the foregoing, Torajasociety is also called ceremonial society because they conduct various ceremonies. In addition, as anhierarchical society, the implementation of the ceremonies is based on the social levels of people such as high nobles (Tanaq Bulawan), middle and brave nobles (Tanaq Bassi), ordinary people orworkers (Tanaq Karurung), and servant classor slave or kaunan (Tanaq Kua-kua) (Paranoan, 1994).

Generally, it can be stated here that several types of ritual speech and traditional dances are disclosed in the death ritual Rambu Soloq', namely (1)the song of Badong (such as movement of feet and hands while singing the death song playedby men in a standing position),(2)the song of death "Osong" sung by men in a sitting position, (3)Mebala Kollong speech (4)speech at the ceremony Mantarima tamu 'receiving guests who came for', the speech is poetry Kadakada to Rampo tongkon, (5)music Ma'marakka'singingthrough a flute', (6)Maqretteng 'poetry of grief', (7)umbating 'funeral song performed by women and others. Furthermore, traditional dances are (8) PaqRanding, (9) PaqKatiaq, (10) PaqPapanggan, (11)Passailo, (12)music of Paq Pompang.
This paper focuses on one part of the ceremony Rambu Solo' or the death ceremony as mentioned in the previous description, namely the songOsong and Mebala Kollong. Ceremony of Rambu Solo' is composed of several parts or stages, but the author focuses his analysis. Both objects of the analysis will be explained one by one in this section. Kollong Mebala poem in the form of speech uttered by an expertpastorAluk Todolo called Tominaa during the ceremony Ma'tammu Tedong 'meeting of all animals, especially buffalo which will be sacrificed or dedicated to which the deceased died. The ceremony is conducted two days before Mantarima Tamu "ceremony of receiving the guest".

Literally, Mebala Kollongmeansto fence the neck or life. If one goes to ask for something to someone else then he struggled to fence or meet the needs of her neck / her life. In relation to ritual of Rambu Solo', Mebala Kollong means of ritual utterance stated to fence or beg the safety of family members and even whole communities in indigenous areas that will carry out the ritual to be spared of any harm of the entire process of the ceremony started from preparation to make loud ceremonies, other preparation processions, the proposing bodies to the barn to "rante" place of the ceremony, reception condolence visitors, bringing, collecting, and pitting buffalo, buffalo cuts, to the implementation of burial. The ritual speech consists of several parts. The first part tells the life story of the deceased. The second part tells the regulations, prohibitions and sanctions against customs violations. The third part tells Singgiq Tedong about the types, functions, and the role of the buffalo in the ceremony "Rambu Solo", and the last part tells about change of name of the deceased from the name of a child, the name as adults, the name at the time was married, name when they already become grandparents, and eternal name when the deceased (informant Pong Pong Osman and Remon).

The next object of study is song"Osong". This song is sung in Ma'tammu Tedong ceremony. This song is played before the speech MebalaKollong or two days before the ceremony Mantarima Tamuconducted. Osongis as a form of art from 


\section{International Journal of Science and Research (IJSR) \\ ISSN (Online): 2319-7064}

Index Copernicus Value (2015): 78.96 | Impact Factor (2015): 6.391

the region, especially North Toraja. Osongis in the form of choral singing organized from umbating (a sad expression song) played collectively by a group of men. Osongis also one of the speech and part of a ritual Rambu Solo' funeral ceremony enriched with interesting symbols if examined by looking at the poetic function contained in it.

Song"Osong" also comprises a brief biography of the deceased containing elements of sadness, flattery, and hope. This song sung by a group of men from the family of the deceased. They sat down on a mat in a circle in front of the house around the corpse, singing Osong. As they marched, chant"Osong"is led by a Tomina called Ambe Osongwho talks, calls and invites them to come together in the court yard of grief.

Means of Osong language poetic is very complex, intertwining to form a rich network effects, and provide vivid and fresh view. These ideas are semiotic in accordance with the choice of words that lead to the sad mood. In semiotics, word'Osong' is a symbol of social status (hierarchy) of royalty of dead people who is sung. Hierarchically, the social status of a person of being sung indicates the presence (royalty) of the Toraja people. It is also related to the number of slaughter (cutting) the status of animals sacrificed for him that is at least 12 buffaloes.

Death chant'Osong' and Mebala Kollong speech of the cultural traditions of Toraja can not be separated from the life of society, as it has several functions. They are as a means of social communication to provide education, teachings, advice, information, etc. to next generation of Torajanese society. Secondly, they identify Torajanese social statusthat the existence of strata or social status of Torajanese people effects on organizing Ma'osongand Mebala Kollong. Thus, the expected songverses should refer to the social status of the people in Osong. However, there is sometimes tominaa using the ritual speech that is supposed to be to noble and brave family, but they provide the speech for ordinary family simply because of social competition 'prestige factor' by revealing a variety of luxury ceremony, ranging from decorating the ceremony venue, the use of music, slaughterhouses excessive sacrifice, but they do the ritual as if their status isnoble or brave.

Besides, the couplets of text 'Kadong Osong' have the values and local wisdom comprising in text of song functions to serve as a preparation for the younger generation for building character. Meanwhile, the fact is that today's young generation does nothave desire to know what the contents of the song. Also, another problem is that theparents, in this casetominaa 'customs experts' do not try to provide understanding and meaning, or encouragement to the younger generation for trying to figure out what the purpose of the ritual chant or speech.

Uttering the death chant of Rambu Solo' ceremony is one form of communication of a group of people to other communities, the bereaved family, that is in fact,they are building social relationships. In conversation, it can be seen thatthe speaker shows the social relationship with the listener, introducing themselves as the member of community, class occupation or other categories. In other words, in denotation text, interactional denotation speakers are constructing social relations as a component of meaning. Words have dramatic social effect in establishing social relationships either they are positive or negative, and harmonious or disharmonis. So,generally, the text is not only mean 'the full expression of the human mind', but also human awareness as social beings. Speaking competence means competence to build social relationships. The loss of these competencies can result in the loss of language etiquette and manners in social interaction (Sandarupa, 2013).

Both objects in this analysis: Osongchant and Mebala Kollongspeech areritual speeches that are sung inAluk Todolo or Tominaalanguage, the languages are not commonly used in daily language and can only be spoken by tominaa and implies a very difficult meaning to understand by the general public especially the younger generation today. The language in the speech, by Sandarupa, et al (2016) is called kada dipasilopak (word pairs and form of parallelism) for the speech in the form of couplets that are paired in parallel and contain meaning and cultural symbols. Therefore, the forms and meanings in the speech draw attention to be studied scientifically, so the author as one of the cultural heir of Toraja intend to present the topic in an attempt to localize in order of preservation.

\section{Review of Literature}

\section{A. Genre In English Toraja}

Commonly, Torajan speech genre used by the Toraja peopleconsists of two kinds, namely kada kada dipamalolo and kada-kada dipasilopak/kada-kada Todolo (Sandarupa, 2016). Kada dipamalolo are words used daily by the general public, such as daily conversations(in families, meetings etc.), a story in the form of a narrative (story ofDodeng, Tulang Didiq etc.), whilekada dipasilopak/kada-kada Todolo are the words of pairs that form parallelism used in ritual ceremonies Aluk Todolo (religious ancestors) either on ceremonial Rambu Tukaq like Massomba Tedong (Hymn of buffalo which includes the philosophy of life of the Toraja), Massuruq Manuk (speech for offering a chicken), or at a ceremony Rambu Solo; such as utterances in Badong (lament by a man), bating (lament by a female) etc.

Osong chant and Mebala Kollong ritual speechin funeral ceremony Rambu Solo' in Toraja culture is oral poetic utterances that are part of the diversity of languages kada dipasilopak. In general, speech in the variety of different types of tropes are expressed in the form of metaphor, parallelism, tautology, and repetition are connotative must be interpreted simbolistically.

\section{B. Parallelism and Metaphor}

Figure of speech is a beautiful language and the metaphors used to beautify or embellish construction of a sentence with the intention of causing an impression of imaginative and can create certain effects through both oral and written speech to the listeners and readers. In principle, figure of speech is divided into four categories: (1) comparison that includes the association, metaphor, personification, allegory, metonymy, sinekdok, symbolic, allegory, (2)contention that includes antithesis, paradox, hyperbole and litotes, (3) innuendo consisting of irony, cynicism, and sarcasm, and 


\section{International Journal of Science and Research (IJSR) \\ ISSN (Online): 2319-7064}

Index Copernicus Value (2015): 78.96 | Impact Factor (2015): 6.391

(4)affirmation in the form of redundancy, repetition and parallelism (Damaryanti, 2014).

Figure of speech should be interpreted connotatively to describe the figurative meaning.Otherwise, denotative meaning cannot be excluded just because it is the basis for interpreting the simbolic connotative meaning. In semiotics, denotation and connotation are two terms that describe the relationship between the signifierand signified and analytic distinction made between two types of sinifieds that denotative signified and connotative signified. The term "denotation" tends to be interpreted as literal meaning or common meaning of a sign, in contrast, the term 'connotation' used to refer to the socio-cultural and personal associations of a sign that is more open to be interpretedthan the meaning of denotation (Chandler, 2014).

According to Barthes (1957 in Hoed, 2014) in a study of culture, connotation theory is developed into a theory of myth. For instance, if the Torajan sees buffalo, denotatively, it is as an animal slaughtered on the feast of the dead to take the meat, or animals used for plowing the fields, then, connotatively, from the standpoint of Bathes' theory, buffalo in culture and myth of the Toraja is a vehicle. He was used as a vehicle to go to puya (a place where the spirits of the deceased according to Aluk Todolo lives) before becoming To membali Puang (people who become gods).

Furthermore, the speech through a death song 'badong' contains a variety of figures of speech. A paralelistic form must be reviewed literally to see the primary or denotation meaning. After that, it is as the foundation to see the secondary or connotative meaning in interpreting the meaning of the symbolism gained by reference to sociocultural community associations.

In semiotics, symbols occur based on metaphor that is the use of words or other expressions to objects or other concept based on figurative or equation (eg. foot of a mountain, foot of a table) and metonymy, that is the name to other objects associated or become attributes (eg, the glassess for someone with glasses) (Kridalaksana, 2001). All symbols involve three elements namely the symbol itself, one or more references, and the relationship between symbols with references. These three things are the basis for all the symbolic meaning.

The symbol is a form that marks something else beyond the symbolic embodiment of the form itself. The symbol inscribed as a flower, for example, refers to a description of facts and carries out a fact for what is called flower as something that exists outside the symbolic form itself. Regarding to this,Peirce (1955, in Sandarupa, 2013)defines symbol as a sign that refers to a particular object beyond the sign itself. The relationship between the symbol as signifier with something that is signified is conventional. Based on the convention, the society interprets character of the relationship between symbols with the object referred to and interprets its meaning.

The symbol cannot be addressed isolatedly, apart from associative relationship with other symbols.Different from the sign, the symbol is a word or something that could be analogizedas a word that has been associated with the interpretation of the user, usage rules ofdiscourse types and the creations of giving meaning which is consistent with the intention of use. Symbols containing and associating with the third item are called symbolic form (Sobur, 2004). Thus, the meaning of the Badong chant speech should be interpreted based on the relationship between language as a signifierwith elements of culture as symbolically connotative signified.

\section{Method}

Problems in this study are assessed by using qualitative research. This research was carried out by participating into certain social situations with observation and interviews to people who are deemed to know about the social situation.

Data are obtained by directly visiting the place (location) of ceremonyRambu Solo' to do participative observation. The primary data are speech, the oral data obtained from the orally field studies (of informers) through recording techniques and note taking. In addition to text of speech, this research data also contain information about the cultural traditions and patterns of life or community action in the form of social relations. Finally, data were analyzed qualitatively.

\section{Result and Discussion}

Speech text data that shows the following entextualizationare obtained from death ritesin ma'tammu tedongceremony, the meeting of all buffalos that will be presented, yet it is preceded by the local indigenous rites.

Here are some examples of Osong chant excerpts narrated in three regional languages which are Toraja, Bugis and Makassar languages. Forexamples,osong chant uttered in ritual Ma'tammu Tedong'ceremony will collect buffalos sacrificedand Ma'kaburu' ritual at funeral. The author chooses one text ofosong in this discussion that is ritual ma'tammu tedong 'buffalo meeting ceremony' recorded in Sa'dan area, northern Toraja regency, in 2016 as attached in the following data.

\section{DATA}

Text of Osong in Ma'tammu Tedongritual 'buffalo meeting ceremony'.

1. Tabe'ambe 'tabe injo'

'The honor to father and mother'

2. Siman kita sola nasang

'also respectful to us all'

3. Angki tannunpa batingki

'we will scatter our grief'

4. Marinjai bulu'

'this village is in sorrow'

5. Sarong bulawanna lipu

'village golden shade'

6. Manganjuri Tuan Londong

'leads into Puang La Londong '

7. Uran di hulu

'rain upstream'

8. Salo'massaro lempa'

\section{Volume 6 Issue 1, January 2017}




\section{International Journal of Science and Research (IJSR)}

ISSN (Online): 2319-7064

Index Copernicus Value (2015): 78.96 | Impact Factor (2015): 6.391

'great flood overflowing'

9. Wai mata maccolo

'as tears'

10. Dipatotoi to maloloe

'fate of young dead people'

11. Pakkaede

12. Tappaja na Tuppu solo '(bela)'

'sorrow continues to plague our lives'

13. Tindak sarira na olai

'rainbow lived'

14. Koro uwe na letei

'lightning skipped'

15. Mangunjuri Tuan Londong

'leads into Puang La Londong'.

16. Leppangan memang ri linoe

'The world is a temporary place '

17. Riolona Puang Ede

'in the presence of God is eternal'

18. Tudangan marajae

'glorious seat'.

19. Pa'di tae randanna

'sorrow that no edges'

20. Apa ma'dokkomo Ambe

'has sat the father'

21. Mairi 'lisa'na tondok

'has presented the entire country'

22.Umbengki'pa'pakilala

'will provide advice/custom'

23. La dirandukmo te ada

'this ceremony will be begun'

24. Tonoran sangka'to dolota

'rules of our ancestors'

25. Anna rapa'katongkonan

'our condolenceswould be calm '.

26. Puang Matua Ambe'ta

'God, the Father'

27. Puang tontong porannu ta

'God continues to be our hope'

28. Ilan a'gan katuan-anta

'in every aspect of our lives'.

29. Den oi upa'ta poupa'

'I hope we all survive'

30. Paraya ta poparaya

'happy and prosperous'.

31. Anta masakke mairi'

'secure and safe'.

Text of Osong chant formssorrow expression (grief), praise and hope in those who died. In analyzing the data, the attention is focused on the characteristics of the denotation text level. In general, it can be said that the entire text segment (1-31) contains two levels of text that says the text level, the narratingand narrated. At the level of denotation text, it is elaborated on what was said in the text (the said or the narrated) (Sandarupa, 2014).

\section{Denotative Text}

Denotative text is the text that consists of a speech or speech group that answers the question 'what is said' by speakers. In this case, the text focuses on the structure of an utterance.

The utterance is called a sentence of text, a representation of denotation where the language is used to talk about something.

In analyzing the data, it focused on the characteristics of the text level of denotation. In general, it can be said that the entire text segment (1-31) contains two levels of text that says the text level of say it (narrate it) and said (narrated).

\section{a. Level text 'says' (saying, narrating)}

Level text says or tells occurs several times in the text segment (1-3), which essentially says that the text that refers to a topic occursthat is a sense of mourning, describingthe condition of the grieving, dispiritingand despair family because of the occurrence of death (level text 12) Tappaja na tuppu solo'(bela)' sorrow continues to plague our lives'. $P a^{\prime} d i$ tae randanna 'sorrow that no edges' (at the level of the text 19).

\section{b. Level text 'said' (the said, the narrated event)}

Text level is characterized by narration. It was marked by a statement in the text segment (4- 31) said that the village is located in the dumps that there is a family member who is still very easy to have gone that is given the title sarong bulawanna lipu' village golden shade (in the text segment 5) and he is expected as protection or shade to the country, but he has returned to heaven in a text called Puang Lalondong (6 and 16). In the text it is said that he was going to walk on a rainbow and to pass a bridge (15-16). Grief on their hearts is like rain upriver that looks like a great flood overflowing (text segment 8). Tears of sadness are like running water, with one of the families of those who died at a young age "dipatotoi to maloloe" (10). It is followed by a text segment (13), and the text segment (2) said that grief is not inexhaustible, the tip base is not trimmed (20).

Defensiveness of death is that this world is a temporary place (17) in front of the Lord (18)eternal 'tudangan marajae' that his father had been sitting (21) and hasbeen attended by the entire family (22), custom advice (23) because customary burial will begin, which was held in the ceremony ma'tammu tedong at bull market. Indigenous ancestor custom will be carried out (23-25). Hold your peace of condolences, our God our Father (27-28) becomes our hope in every aspect of our lives. And may we all survive, be happy and prosperous (29-31)

Indigenous custom entrenches like bamboo roots and ancestors are lowering truths (23-25). Markers of narration are again found in the text segment which states the custom will start from the roots. Osong in the song can be seen at the level of the following text:

\section{La dirandukmo te ada}

'the ceremony will be begun'

\section{Tonoran sangka'to doloa} 'rules of our ancestors'

\section{Anna rapa'katongkonan}

'hold our peace of condolences.

Furthermore, it is clarified that under any circumstances, the customs and the ancestors' truth is that in the present state of 


\section{International Journal of Science and Research (IJSR) \\ ISSN (Online): 2319-7064}

Index Copernicus Value (2015): 78.96 | Impact Factor (2015): 6.391

our sorrow because of the desire and compassion to those who have died. Grief for being left by our lovely one is boundless.

Data analysis was based on a sample of Mebala Kollong ritual speech. Fragments of the following couplet are a speech used to greet the present condolence visitors.

1. to unnisung lan te Rante kalua'

'people sitting in the vast plains'

2. to untorroi lan te tandung sea-sea

'people living in very broad plains'.

Both forms of parallelism in the coupletare the opening to greet the condolence visitors. The second line (untorroi tandung sea - sea) is a form of repetition of the first line (unnisung - rante kalua') and bothbasically have same meaning. However, denotatively (primary meaning) as well as simbolistic-connotatively (secondary meaning), untorroi implies a broader meaning that means 'staying'than unnisung means specificallysitting. Likewise in the same way, the phrase tandung sea - seameans vast plains that have higher and broader meaning thanrante kalua' that is a plain as usual meaning. In this case, the words of the first line has related inclusions with the words on the second row in the sense that unnisung (sit) is a form of hyponym from the worduntorroi (live) as superordinate because people who unnisungmust be untorroi and certainly cannot be reversed.

Both phrases rante kalua'and tanjung sea - seain the line metaphorically depict a traditional party means a deceased person has a high social status, even denotative place or arena of ceremony described as a vast field once actually it is not veryvast. Yet,connotativelysymbolistically,parallelism form is a view that the ceremony carried out is a highest traditional ceremony becausethe people who the ceremony is held is a nobleman (tana' bulawan). Communities with social status tana'karurung (ordinary people) and tana' kua-kua (slave) will not be held a ceremony for in place with a large ceremonial usinga speech as described above.

Following couplet provides an overview of the ritual speech in Mebala Kollong as words booked by ancestors for posterity and should be inherited and implemented in family life and society.

\section{Kada disedan sarong}

Words hanged (leant on) saroong

Bisara ditoke 'tambane baka

talk hanged (not leant on) basket tie

In the second row of paralelism, wordkada is parallel withwordbisara and disedan sarong is parallel withditoke 'tambane baka. Nonetheless, the second line comprises a broader and sharper meaning than the first line of both primarily and secondarily. Thus, the word 'words hanged with saroong' primarily is words which hung like a saroong(width hood worn by Toraja women to traditional party) but had to lean on pole or wall. While, the 'talk hanged with basket tie' (big basket brought behind by Toraja women to traditional party or to another place to load something in large quantities) primarily means a talk derived directly like baskets hanged but not leaning against a wall or pole. In terms of semantics, kada is a hyponym of bisara as superordinate and disedan is a hyponym of ditoke'as superordinate.

Metaphorically two phrases disedan sarong and ditoke'tambanE baka equated with words or phrases delivered from the top ancestor to (bring) posterity like saroongs and baskets hung from the top to down. Connotatively symbolistically, two phrases symbolize the words and phrases addressed are the messages from the ancestors in which must be protected well (like a saroong as a head and body protectionthat should be hung with arest in a safe place) in daily life. Moreover, the second line confirms that the message of these ancestors must be held well, accepted in the heart, and implemented in whole life in the midst of the family and society like tying something tightly in a big basket so as not to spill and lose and then hung on middle of a room in a house.The following verses describe the situation when the person is held a ceremony for experiencing pain before death.

\section{Makuyu langkan}

'unhealthy like an eagle

Masaki manuk-manuk

'sick like a bird'

Denotatively, parallelism abovebasically contains the same primary meaning, but the second line consists of the broader meaning of the first line. Similarly, first line semantically has an entailment relation (inclusion) with the second line because the word makuyu is hyponym of wordmasaki which is superordinate, because if an animal or a person is in a state makuyu (less healthy), surely he must be masaki (sick), but cannot be reversed. Likewise in the same way, the word langkan (eagle) is hyponym of wordmanuk - manuk (bird) as the superordinate, because eagle is certainly a part of bird but cannot be otherwise.

Metaphorically, the couplet is a symbol of the physics of sick person in which he is compared to bird (eagle) whichissick. He is like a painful eaglethat is not able to flyto search for food and just to resign on the spot waiting for death. Similarly, a mighty man in a family and society is helpless when he issick.

3. Iko balian, panggaragannoko tolino, silopak tallangnako bonga

You, balian, handmade, pairs of bambboo of bonga Iko bonga, pa'tampanako deata, silopak tallangnako balian

You, bonga, created by God, pairs of bamboo of balian

Denotatively, parallelism forms sho that quality the second line meaning is deeper than the first line such as bonga created-deata dengan balian - made - human. In this case, bongais created byGods and Puang Matua naturally and invisiblely, while balian, its status is created by humans artificially and visiblely.

The first line explains the existence of balian, a buffalo made by human. It is a compatiblepartner ofbonga. Instead, 


\section{International Journal of Science and Research (IJSR) \\ ISSN (Online): 2319-7064}

Index Copernicus Value (2015): 78.96 | Impact Factor (2015): 6.391

bonga, a buffalo is created byGod. It is a fit partner of balian. Both lines are parallelism in reciprocity to illustrate that in rapasan ceremony ie. Rambu soloq, high level ceremony, balian and bongaarewhole unit and complete each other as well as are inseparable as in metaphor expressionsilopak tallang (pairs tightly like a pair of two parts of bamboo joints) in which it is called by Hurford and Heasley (1987) as mutually compatible.

In etymology, the word balianderives from bali means a spouse, a friend, or an opponent. If the word is derived by prefix 'si-'to become 'sibali', then there is reciprocity which means that each pair. So, if a man and a woman sibali then they will become husband and wife.

In relation to that, buffalo status changedto be balian when it has been castratedso that the first line balian called "creation" of man. On one hand, it is originally a buffalo so that he became a symbol of the male. However, when it is already neutered, it also becomes a symbol of a woman because it is no longer entirely a male even if it does not turn into a female. Thus, the buffalo represents the men and women that are connotatively simbolisticallyit becomes a symbol of a whole and inseparable unit figured out by Toraja society.

Besides,bonga/bonga suraqis a special buffalos (spotted buffalo). Color of the buffalo is created naturally when it is born, so it is believed as created by God.It isreciprocally paired with balian in a ritual show rambu soloq in Toraja culture. It is a symbol of wealth and high social status or symbol of nobility (Tanaq Bulaan and Tanaq Bassi).Also, it becomes torches and lights as well as the heritage of indigenous people in a high-level ceremony Rambu soloqas in the following expression:

\section{Iko bonga pantaranakna bintoen tasak \\ 'You, spotted buffalo, a small pet of bright star'}

In addition, one of the buffaloes that plays an important role in ritual speech Mebala Kollong is Tekken Langiq, ie.one horn is facing down (tanduk sokko), whileother horn is facing upwards (tanduk tarangga). Expressions about the rules in the form of restrictions and sanctions must be adhered to during the ceremony to maintain security and safety for all the family and condolence visitorswritten in Passomba Tedong particularly when it comes to buffalo Tekken Langiq as in the following speech:

4. a1) Kedeng-Komi lapalutu tombang,

If you disturb puddles,

a2) lapaossak bala tampo

step ondike fence.

b1) Laullulluq te alukna kabotoan kullaq

step on this ceremony, place of sunset,

b2) Te sangkaqna rampe matampuq

'This is western ceremony'

c1) Lanatemmeqko Sokko sangbali Rokko laqtana padang,

'Would be pressed by tanduk sokko down to a soil crack',

c2) Lanaserokko tarangga sangpiak Lako matallo matampu'
'Would be butted by tarangga to the east and to the west'

Couplets above are form of parallelism with each repetition in the second row (a2, b2 and c2), all of which reinforces the meaning of the words in the first row (a1, b1, and c1). couplet (a1) and (b2) metaphorically implies that if anyone want to make a fuss and mess up (lapalutu tombang / al and lapaossak bala tampo / a2) custom ceremony of rambu soloq(aluk kabotoan kullaq / b1 and sangkaq rampe matampuq / b2), then he will be punished or given penalties as stated in the couplets ( 11 and $\mathrm{c} 2$ ). Customary law and aluk as proclaimed in Pasomba Tedong symbolized at the second buffalo horn Tekken Langiq which one is down (Sokko) and one is up (tarangga) will tear apart the lives of condemned till they are swallowed into the earth and slammed into the point of sky (sadistic die).

To prevent, it is necessary to create a good social relations among all the family during the ceremony takes place, it means not to made a scene. Likewise with pets, especially buffaloes that will be sacrificed should be treated accordingly and prayed for each type of buffalo as contained in the verses Mebala Kollong to avoid a catastrophe. Furthermore, the most important is prayer requesting to the Almighty to grant salvation and blessing during and after the ceremony. This can be seen in the following stanzas:

5. a) Pangngandona to maqrapu tallang kumua:

His prayer was a clump of bamboo he said,

b1) Denno upaq dipoupaq,

Hopefully lucky

b2) Paraya dipoparaya blessingblessed

c1) Anna buqtu Kalimbuang boba, So there is a big spring

c2) Anna somba uai eye tang sore - sore

It emerges unstoppable spring

d1) Lako shoot bulawana indeq indoq dipoindoq,

For these goldendescendants mother is mothered

d2) nenek diponeneq

ancestor is worshipped

In the verses above, the first line (a) is an introduction which is a pray from the whole family in which is metaphorically assumed with a bamboo cluster (rapu tallang) ie. An appealof blessing for them in form of a tautology syntagmatic (b1dan b2). The next stanza (c1 and c2) is a request for family from dead mother-grandmotherin the form of parallelism and metaphor. Metaphorically, their expectations about the abundant blessings which is always given to their lives are compared as A wide spring that endlessly flows the water. Meanwhile,the purposes of such appealare to which all descendants (children and grandchildren) metaphorically are assumed to bud or descent gold (tarukbulawan) because they descend from noble family (tanaq bulawan) of the dead mother - grandmother (indoq dipoindok - neneq diponeneq), which means mother of children and grandmother of grandchildren. Tautology form ( $\mathrm{d} 1$ and $\mathrm{d} 2$ ) is affirmation of owners of taruk bulawan (children and grandchildren) who are in hope and prayer. 


\section{International Journal of Science and Research (IJSR) \\ ISSN (Online): 2319-7064}

Index Copernicus Value (2015): 78.96 | Impact Factor (2015): 6.391

Tautology forms areword repetition syntagmatically that is parallelism paradigmatically as in example 6 (b1, b2 and d2, d2) that is one of the characteristics of ritual speech of Toraja culture in general and Mebala Kollongin particular.

In a culture Aluk Todoloof the Toraja people, the role and function of buffalo with its own symbols respectively as the three described above, in addition to the types of other buffalo based on the myth that there is a process of transition from earthly life to the next life after death in the world. A dead person will move from heaven to a stop-over place called Puya.

The move was experiencing two different processes. On the one hand, if a person does not hold a ceremony for asaluk, then his presence will be rejected in Puya and will becomebombo (life in a negative sense) which can disrupt the lives of the families left behind at any time. On the other hand, people who is held a ceremony forasaluk will have provision for transformation of the world (lino) to puya, such as the buffaloes sacrificed at same time as a means of transportation so that he can get there safely and accepted, and live in peace. Then, they will be to membali Puang (become gods) and then go back and stay in the sky (torro dao kapuanganna) and live with God in peace. Next, they will give a blessing to the family who has carried out theirdeath ceremony on earth (dipasundun alukna lan lino). Based on the belief, rambo soloq is heldaccording to one's status at the expense of buffalo in accordance with the type and amount. That is one of the unique culture of Toraja.

\section{Conclusion}

Based on the description above, it can be concluded that:

1) Osong chant and Mebala Kollong speech is a ritual speech at the ceremonyRambu Soloq of Toraja Culture when carrying bodies to rante, venue of the ceremony along with collects all the buffalo to be sacrificed to ask for salvation for all the family and all the condolence visitorsin order of deliverance from all danger during and after the ceremony.

2) Osong chant ritual speech and Mebala Kollongare akada silopak (parallelism and pair speech) in the form of stanzas that poured in forms of tropes or figure of speech such as repetition, symbolic, metaphor, and parallelism, and tautology.

3) Because it is a trope, Osong chant and Mebala Kollong ritual must be explained by denotation or primer and connotation meaning or secondary meaning to interpret cultural symbols.

4) Geerally, based on denotative and connotative meaning, the meaning of second line of each stanza is deeper and broader than the meaning of the first line becausethe meaning of the second row gives emphasis to the meaning in the first row.

5) Particularly, paradigmatic form between lines in each stanza shows that the words in the first line is hyponym of words in the second row as the subordination and the clause on the first line that inclusion with a clause on the second line.

6) Connotatively simbolistically, Osong chant ritual speech and Mebala Kollong express the relationship between man and man, man and animals as well as socialcultural religious values such as petition, respect, rules-bandoubt, hope, majesty, and pray.

7) It is needed to carry out more researches systematically and in-depth about the topic of the ritual speechin this analysis as well as other ritual speech in the culture of Toraja to document efforts in order to preserve the culture.

\section{References}

[1] Ada', John Liku. 2009. "Manusia dan Lingkungannya Dalam Falsafah Religius Toraja." Dalam Andin, Michael. (ed.), Saatnya Bertindak dan Berubah. (hal. 53-72) Jakarta : Pukat Media.

[2] Chandler,Daniel. 2014. Semiotics for Beginners. $\mathrm{http} / /$ :visualmemoty.co.uk/Daniel/Documents/S4B/Sem12.html

[3] Damaryanti, 2014. Macam macam majas dan contohnya lengkap.www.kopiireng.com/search/label/bahasa Indonesia/agustus2016.

[4] Dharmojo, 2005. Sistem Simbol dalam Munaba Waropen, Papua : Pusat Bahasa Departemen Pendidikan Nasional.

[5] Hoed, Benny H. 2014. Semiotika dan Dinamika Sosial Budaya. Depok: Komunitas Bambu

[6] Hurford, James R and Haesley, Brendan. 1983. Semantics : a courbook. Cambrigde University Press.

[7] Kobong, 1983. Manusia Toraja :Dari Mana Bagaimana - Ke mana. Rantepao : Institut Theologia.

[8] Kridalaksana, 2001. Kamus Linguistik. Jakarta: Gramedia

[9] Manta', Yohanes. 2003. Sastra Toraja “Kumpulan Kada-kada Tominaa Dalam Rambu Tuka' dan Rambu Solo'.Sangalla"Tana-Toraja.

[10] Paranoan, M. 1994. UpacaraKematian Orang Toraja. Analisis Psiko-Sosio-Kultural. Rantopao: Percetaka Sulo.

[11] Pierce, S. 1955

[12] Sandarupa, Stanislaus. 1989. Tropes, Symbolism, Rhetorical Structure, Structure Pararelism of Structure in Toraja. Amerika Serikat: The University of Chicago.

[13]_ 2009. Politik Mitos Orang Toraja. Kompas. Hal 38.

[14] 2013. Mediasi Semiotik Dalam Studi Antropolinguistik. Pidato Guru Besar. Faklutas Ilmu Budaya Universitas Hasanuddin.

[15] . 2014

[16] Sandarupa, dkk. 2016. Kambunni': Kebudayaan Tallu Lolona Toraja. Makassar: De La Macca

[17] Sarira, Y.A.1996. RambuSolo' dan Persepsi Orang Kristen Tentang Rambu Solo'. Rantepao : Pusbang Gereja Toraja.

[18] Sobur. Alex. 2004. Semiotika Komunikasi. Bandung : PT. Remaja Rosdakarya.

[19] Veen H. van Der and J. Tammmu. 1972. Kamus Toradja-Indonesia. Rantepao. Jajasan Pengurus Kristen Toradja. 


\section{International Journal of Science and Research (IJSR) \\ ISSN (Online): 2319-7064}

Index Copernicus Value (2015): 78.96 | Impact Factor (2015): 6.391

\section{Author Profile}

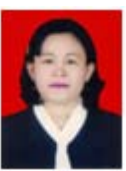

Naomi Patiungis anIndonesian Language lecturer at Nusantara Jaya Nursing Academy, Makassar, Indonesia. She was born in Tana Toraja, South Sulawesi, Indonesia onOctober $29^{\text {th }}, 1969$. She got her bachelor degree (S.S.) in 1996 at Letter Faculty of Hasanuddin University and her magister degree (M.Hum.) in 2010 at Postgraduate Program in Indonesian Language Study of Hasanuddin University. In 2013 up to present, she continued her study to get her doctorate degree on Linguistics at Faculty of Cultural Sciencesat Hasanuddin University, Makassar, Indonesia. This paper is a part of her dissertation which is supervised byProf. Dr. Tadjuddin Maknun, S.U. (promotor), Prof. Dr. M. L. Manda, M.A., M. Phil. and Prof. Dr. Hamzah A. Machmoed, M.A.(Copromotors). 